\title{
Are Immigrants in Favour of Immigration? Evidence from England and Wales
}

\author{
${ }^{1}$ Business School - Economics, Newcastle University, 5 Barrack Road, Newcastle upon Tyne NE1 4SE, UK, E-mail: \\ nils.braakmann@newcastle.ac.uk, john.wildman@newcastle.ac.uk \\ ${ }^{2}$ Department of Economics, The University of Sheffield, 9 Mappin Street, Sheffield S1 4DT, UK, E-mail: \\ m.waqas@sheffield.ac.uk
}

\begin{abstract}
:
Using the UK Citizenship Survey for the years 2007-2010, this paper investigates how immigrants view immigration and how these views compare to the views of natives. Immigrants who have been in the UK longer are similar to natives in being opposed to further immigration, while recent immigrants are more in favour of further immigration. Labour market concerns do not play a large role for either immigrants or natives. However, there is some evidence that financial and economic shocks can increase anti-immigration sentiments.
\end{abstract}

Keywords: immigrants, attitudes/views towards immigration, immigrant integration, financial worries, labour immigration

JEL classification: J15, J61, J82

DOI: $10.1515 /$ bejeap-2016-0029

\section{Introduction}

Questions of immigration policy and opinions on immigration in general have recently taken centre stage in various political decisions, such as the referendum vote in the UK to leave the European Union or the ultimately successful run for the US presidency by Donald Trump. This paper considers the views of immigrants and natives towards further immigration as well as their determinants.

Most of the literature concerned with support for, or opposition to, immigration has focused on natives, while the views of immigrants already in a host country have received less attention. ${ }^{1}$ There are, however, marked differences between natives and immigrants: According to the UK Citizenship Survey (Department for Communities and Local Government and Ipsos MORI 2007-2010) around 71\% of respondents are opposed to further immigration. ${ }^{2}$ Unsurprisingly, this number increases to $83 \%$ of all natives, but even among immigrants almost $50 \%$ oppose further immigration. However, immigrants are themselves not homogeneous, for example in terms of the time they have already spent in a country and their degree of integration into their host country's culture. To capture this heterogeneity, we consider two groups of immigrants: those who have been in the country for 5 years or more (earlier immigrants) and those who have been in the country for fewer than 5 years (recent immigrants). Among the former $53 \%$ of respondents are opposed to further immigration, while only $33 \%$ of recent immigrants oppose further immigration, already illustrating the importance of the aforementioned heterogeneity.

In this paper, we investigate these differences in attitudes towards immigration. ${ }^{3}$ Our results show that immigrants who have been in the country for five years or more have views on immigration that are similar to those of natives, i. e., they are more likely to oppose further immigration than recent immigrants. Recent immigrants are the least likely to oppose further immigration. We find that these results are robust to the inclusion of socio-economic characteristics. Labour market concerns do not seem to influence views; however, financial and economic shocks are associated with anti-immigration responses.

The literature investigating the attitudes of immigrants towards immigration and determinants of immigrants' attitudes is sparse. ${ }^{4}$ Most of the research concerning the attitudes of immigrants towards immigrants covers the US (see, for example, Binder, Polinard \& Wrinkle, 1997; Hood, Morris \& Shirkey, 1997; Polinard, Wrinkle \& de la Garza, 1984; Sanchez \& Masouka, 2010). A recent European addition on this topic is by Just and Anderson (2015). They use data from 5 rounds of the European Social Survey conducted 2002-2011 for 18 European countries. They explore two opposing channels of immigrants' attitudes towards immigration: (a) shared experiences, unity and ties with other immigrants and (b) integration into the host country. The former 
channel leads to supportive attitudes as immigrants are keen to build communities. The latter channel generates negative attitudes towards further immigration as immigrants adopt the views of natives.

The literature generally points towards the following reasons why immigrants (and natives) might be opposed to future immigration. Firstly, immigration may be perceived to have a detrimental effect on the labour market prospects of natives and immigrants who are already in the host country. ${ }^{5}$ This opposition might also differ between earlier and more recent immigrants, as well as natives, due to differences in their (perceived) substitutability in the labour market. If, for example, new immigrants are closer substitutes for recent immigrants than for earlier immigrants or natives, opposition in this group might well be more substantial. ${ }^{6}$ On the other hand, pro-immigration views may arise because respondents consider immigration to be beneficial for the host country's economy or for their businesses (see, for example, Dustmann, Frattini \& Preston, 2013; Hainmueller \& Hiscox, 2007; Manacorda, Manning \& Wadsworth, 2012; Ottaviano \& Peri, 2012).

Secondly, all three groups may be opposed to further immigration out of concern for public services. If immigration places a strain on public services, such as education (see, for example, Betts \& Fairlie, 2003; Geay, McNally \& Telhaj, 2013; Ohinata \& van Ours, 2013; or Schneeweis 2013), public safety (for example, Bell, Fasani \& Machin, 2013), health care or welfare, users of these services, regardless of their origin, might oppose further immigration.

Thirdly, there may be opposition to immigration because of a fear that it may threaten the culture of the host nation. This argument is primarily relevant for natives, but also to some extent for existing immigrants, who may view immigration as an erosion of social cohesion (Hickman, Crowley \& Mai, 2008; Saggar et al., 2012). This may be especially true if the countries that are the source of immigration are changing over time. For example, in the UK many of the earlier immigrants were from Commonwealth/ex-Empire countries, whereas many recent immigrants are from Europe.

Earlier and recent immigrants may hold different views on further immigration because the former have integrated into the host society. Manning and Roy (2010) provide some evidence on this process, although they refer to assimilation rather than integration. They find that immigrants - with the exception of Irish and Italians - consider themselves more British the longer they stay in the UK and that even immigrants from a diverse range of background, integrate successfully. Given this assimilation, it appears entirely possible that immigrants also adopt the natives' resistance to further immigration. ${ }^{7}$ On the other hand it is possible that immigrants favour further immigration, especially from their own country of origin, out of feelings of shared experiences, unity and ties with other immigrants (Just and Anderson 2015), because it enables them to form links with people who share the same culture and heritage or simply because they want to bring their families to the host country in the future.

The remainder of this paper is organised as follows. Section 2 describes the dataset, Section 3 presents empirical strategy, threats to identification strategy and methodology used in this paper, Section 4 presents results and Section 5 concludes.

\section{Data}

This paper uses three waves (Department for Communities and Local Government and Ipsos MORI 2007-2010) of the UK Citizenship Survey. ${ }^{8}$ The survey is conducted in England and Wales, covers people aged 16 and above and consists of a core sample of around 10,000 individuals and a minority ethnic boost sample of around 5,000 individuals. For this paper respondents are categorized on the basis of country of birth of respondent and country of birth of their mother and father in order to differentiate between immigrants and natives. This classification gives us the six broad categories listed below. These classifications are subdivided on the basis of ethnicity and self-assessed nationality and are shown in Table 1.

1. Respondents born in the UK with both parents born in the UK.

2. Respondents born in the UK with one parent born abroad.

3. Respondents born in the UK with both parents born abroad.

4. Respondents born abroad with both parents born in the UK.

5. Respondents born abroad with one parent born abroad.

6. Respondents born abroad with both parents born abroad.

Table 1: Respondent categorisation based on ethnicity and nationality (2007-2010). 


\begin{tabular}{|c|c|c|c|c|}
\hline Sr. & \multicolumn{2}{|c|}{ Categorisation (2007-2010) } & & \multirow{2}{*}{$\begin{array}{l}\text { Total } \\
\mathbf{4 5 1 5 2} \\
23,600\end{array}$} \\
\hline & \multicolumn{3}{|c|}{ Respondent born in the UK with both parents born in the UK } & \\
\hline \multirow{6}{*}{1} & 1.1 & White (based on ethnicity) & 22,560 & 23,592 \\
\hline & 1.2 & Non-White (based on ethnicity) & 1,032 & \\
\hline & 1.3 & $\begin{array}{l}\text { British + Other (based on national } \\
\text { identity) }\end{array}$ & 20 & 23,600 \\
\hline & 1.4 & $\begin{array}{l}\text { Only British (based on national } \\
\text { identity) }\end{array}$ & 21,691 & \\
\hline & 1.5 & Only Other (based on national identity) & 1,889 & \\
\hline & \multicolumn{3}{|c|}{ Respondent born in the UK with one parent born abroad } & 1,959 \\
\hline \multirow{6}{*}{2} & 2.1 & White (based on ethnicity) & 866 & 1,959 \\
\hline & 2.2 & Non-White (based on ethnicity) & 1,093 & \\
\hline & 2.3 & $\begin{array}{l}\text { British + Other (based on national } \\
\text { identity) }\end{array}$ & 32 & 1,959 \\
\hline & 2.4 & $\begin{array}{l}\text { Only British (based on national } \\
\text { identity) }\end{array}$ & 1,754 & \\
\hline & 2.5 & Only Other (based on national identity) & 173 & \\
\hline & \multicolumn{3}{|c|}{ Respondent born in the UK with both parents born abroad } & 4,287 \\
\hline \multirow{6}{*}{3} & 3.1 & White (based on ethnicity) & 298 & 4,286 \\
\hline & 3.2 & Non-White (based on ethnicity) & 3,988 & \\
\hline & 3.3 & $\begin{array}{l}\text { British }+ \text { Other (based on national } \\
\text { identity) }\end{array}$ & 138 & 4,287 \\
\hline & 3.4 & $\begin{array}{l}\text { Only British (based on national } \\
\text { identity) }\end{array}$ & 3,658 & \\
\hline & 3.5 & Only Other (based on national identity) & 491 & \\
\hline & \multicolumn{3}{|c|}{ Respondent born abroad and both parents born in the UK } & 258 \\
\hline \multirow{6}{*}{4} & 4.1 & White (based on ethnicity) & 244 & 258 \\
\hline & 4.2 & Non-White (based on ethnicity) & 14 & \\
\hline & 4.3 & $\begin{array}{l}\text { British + Other (based on national } \\
\text { identity) }\end{array}$ & 3 & 258 \\
\hline & 4.4 & $\begin{array}{l}\text { Only British (based on national } \\
\text { identity) }\end{array}$ & 220 & \\
\hline & 4.5 & Only Other (based on national identity) & 35 & \\
\hline & \multicolumn{3}{|c|}{ Respondent born abroad with one of the parents born abroad } & 275 \\
\hline \multirow{6}{*}{5} & 5.1 & White (based on ethnicity) & 156 & 275 \\
\hline & 5.2 & Non-White (based on ethnicity) & 119 & \\
\hline & 5.3 & $\begin{array}{l}\text { British }+ \text { Other (based on national } \\
\text { identity) }\end{array}$ & 14 & 275 \\
\hline & 5.4 & $\begin{array}{l}\text { Only British (based on national } \\
\text { identity) }\end{array}$ & 204 & \\
\hline & 5.5 & Only Other (based on national identity) & 57 & \\
\hline & \multicolumn{3}{|c|}{ Respondent born abroad with both parents born abroad } & 14,469 \\
\hline \multirow{5}{*}{6} & 6.1 & White (based on ethnicity) & 1,192 & 14,465 \\
\hline & 6.2 & Non-White (based on ethnicity) & 13,273 & \\
\hline & 6.3 & $\begin{array}{l}\text { British + Other (based on national } \\
\text { identity) }\end{array}$ & 511 & 14,469 \\
\hline & 6.4 & $\begin{array}{l}\text { Only British (based on national } \\
\text { identity) }\end{array}$ & 7,823 & \\
\hline & 6.5 & Only Other (based on national identity) & 6,135 & \\
\hline
\end{tabular}

Note: There are 304 missing values in country of birth identifiers due to unknown country of birth of the respondent, his mother or his father. 13 missing in ethnicity.

In our main specification, we focus on groups 1 and 6 . We refer to the first group as "natives" and group 6 as "immigrants". While this classification may be imperfect we believe that they provide a mechanism for distinguishing between natives and immigrants. These two categories make up $85 \%$ of the total respondents, with $55 \%$ classed as natives and $30 \%$ classed as immigrants. The remaining $15 \%$ of respondents fall into one of the other four groups making it difficult to assign individuals to "natives" or "immigrants".

As robustness checks we try two different classifications: Firstly, we classify anyone born in the UK as a native (groups 1, 2 and 3) and compare these to group 6. Secondly, we divide the sample into three groups: (i) "immigrants", i. e., overseas-born individuals with at least one overseas-born parent (groups 5 and 6); (ii) "natives with immigration background", i. e., either overseas-born individuals with only UK-born parents (group 
4), for example, children of British soldier families born while stationed in Germany, or, UK-born individuals with at least one overseas-born parent (groups 2 and 3); and (iii) "natives", i. e., UK-born with no foreign-born parent (group 1). We will see that our results do not depend on the exact definition of immigrants and natives that we use.

Immigrants are further divided into two categories based on the length of time they have lived in the UK. Individuals who were born overseas are asked whether they have lived in the UK for five years or more. We use this question to divide our group into earlier immigrants (five years of more in the UK) and recent immigrants (less than five years in the UK). While the categorisation of earlier and recent is data driven we believe that the five-year time horizon is important. For example, Manning and Roy (2010) show that immigrants start to change their attitudes slowly a year after their arrival into the UK, and that, subsequently, integration becomes increasingly quick. Therefore, taking 5 years as a threshold to identify earlier and recent immigrants is plausible enough to determine the heterogeneity in the attitudes of immigrants.

Our key dependent variable is the answer to the question, "Do you think the number of immigrants coming to Britain nowadays should be increased, reduced or should it remain the same?" A follow-up question to respondents then asks whether the number should be increased or reduced by a little or a lot. For most of the analysis, "increased a lot", "increased a little" and "remain the same" are grouped together, as all indicate that the respondent does not want immigration to be cut. People replying "increased a lot" and "increased a little" are clearly in favour of immigration, while those replying "remain the same" also hold no opposition to further immigration. We also group the choices "reduced a lot" and "reduced a little" as both indicate a wish to see immigration reduced. Respondents selecting "cannot choose" are excluded from the analysis. This generates an indicator variable of whether an individual is opposed to further immigration.

We assess the robustness of these choices in two ways: We run ordered probit models on the original (5 category) outcome variable and we also run the same models without individuals who replied "remain the same". The results are largely unchanged.

Our data also contain information on survey year, gender, age, ethnicity, religion, practicing religion and region of residence, all of which are included as control variables. Furthermore, we also have data on employment status and income, allowing us to investigate the roles that the labour market and social status play in determining attitudes towards immigration. Control variables for all the models are the same unless mentioned. Dummy indicators are generated for all of these variables.

The omitted category for the variable survey year is "wave 2007-2008", for gender it is "male", and "London" for the regions. In terms of ethnicity, we distinguish between "White", "Black", "Subcontinent", "Chinese", "other Asian", "mixed race" and "other ethnicities". "Black" ethnicity is comprised of "Black Caribbean", "Black African" and "other black ethnicities". Subcontinent includes "Indian", "Pakistani" and "Bangladeshi" ethnicities. For the ethnicity variable "white" is the omitted category. Eight dummies are created for the religion variable and are labelled as, "Budh", "Hindu”, "Jewish”, "Muslim”, "Christian”, "Sikh", "no religion” and "other religion". "Christian" is the omitted dummy for religion. For the variable whether a person is "practicing religion or not", "not practicing religion" is considered as the reference category. "Employed" is the reference group for the employment status dummies. Income of the respondent is used to proxy for social status. The reference category for the income variable is " $£ 10,000-£ 15,000$ ".

These control variables have been included because most of the literature on attitudes uses these variables in their regressions (see, for example, Dustmann and Preston (2007)). Although some variables that may be found in other literature on attitudes could not be included because of the data restrictions (for example data on the formal acquisition of citizenship of immigrants is not available).

Our key variable of interest is an individual's migration status. Being native serves as the reference group enabling us to explore differences between natives, earlier immigrants and recent immigrants.

One variable that we would have liked to have considered more fully is "education". However, in our data only individuals under the age of 65 are asked their educational status, limiting our analysis. We estimated models using the whole sample, omitting the education variable, and for the subset of under 65s including the available education information. The estimates of the models for the under $65 \mathrm{~s}$ show that the coefficient of our key variable, migrant status, remained largely unchanged; however, we found that higher education is associated with favourable views towards immigration for natives, earlier and recent immigrants.

Finally, we also use the 2009/2010 data that contain additional information on economic circumstances. Four types of economic worries are considered, specifically whether the respondent has lost his/her job, experienced a drop in income, had to cutback spending on necessities such as food or shelter, or had to cutback spending on non-necessities, such as entertainment expenses or charity donations in last twelve months. The reference category for this variable is "not reporting any worry". These four additional models are estimated for the pooled sample and for natives, earlier and recent immigrants separately. These are included in separate models to consider how the onset of financial difficulties affects support for immigration. 
Table 2 provides descriptive statistics for our sample.

Table 2: Descriptive statistics (2007-2010).

\begin{tabular}{|c|c|c|c|c|c|c|}
\hline \multirow[t]{2}{*}{ Variables } & \multirow{2}{*}{$\begin{array}{l}\text { Natives } \\
\text { Mean }\end{array}$} & \multirow[b]{2}{*}{ Std. Dev. } & \multicolumn{2}{|c|}{ Earlier immigrants } & \multicolumn{2}{|c|}{ Recent immigrants } \\
\hline & & & Mean & Std. Dev. & Mean & Std. Dev. \\
\hline $\begin{array}{l}\text { Reduce } \\
\text { migration }\end{array}$ & 0.823 & 0.382 & 0.530 & 0.499 & 0.334 & 0.472 \\
\hline $\begin{array}{l}\text { Increase } \\
\text { migration }\end{array}$ & 0.177 & 0.382 & 0.470 & 0.499 & 0.666 & 0.472 \\
\hline $\begin{array}{l}\text { Out of labour } \\
\text { force }\end{array}$ & 0.313 & 0.464 & 0.323 & 0.468 & 0.218 & 0.413 \\
\hline Self-employed & 0.069 & 0.254 & 0.082 & 0.274 & 0.039 & 0.193 \\
\hline Unemployed & 0.150 & 0.357 & 0.162 & 0.368 & 0.181 & 0.385 \\
\hline Employed & 0.468 & 0.499 & 0.434 & 0.496 & 0.563 & 0.496 \\
\hline Male & 0.449 & 0.497 & 0.484 & 0.500 & 0.538 & 0.499 \\
\hline Female & 0.551 & 0.497 & 0.516 & 0.500 & 0.462 & 0.499 \\
\hline Age & 50.262 & 18.589 & 46.622 & 15.422 & 31.319 & 9.449 \\
\hline $\begin{array}{l}\text { Income below } \\
5 \mathrm{~K}\end{array}$ & 0.189 & 0.392 & 0.257 & 0.437 & 0.344 & 0.475 \\
\hline $\begin{array}{l}\text { Income } 5 \mathrm{~K} \text { to } \\
10 \mathrm{~K}\end{array}$ & 0.209 & 0.407 & 0.198 & 0.399 & 0.165 & 0.371 \\
\hline $\begin{array}{l}\text { Income } 10 \mathrm{~K} \text { to } \\
15 \mathrm{~K}\end{array}$ & 0.156 & 0.363 & 0.158 & 0.365 & 0.163 & 0.369 \\
\hline $\begin{array}{l}\text { Income } 15 \mathrm{~K} \text { to } \\
20 \mathrm{~K}\end{array}$ & 0.117 & 0.321 & 0.107 & 0.309 & 0.096 & 0.294 \\
\hline $\begin{array}{l}\text { Income } 20 \mathrm{~K} \text { to } \\
30 \mathrm{~K}\end{array}$ & 0.158 & 0.365 & 0.149 & 0.356 & 0.125 & 0.331 \\
\hline $\begin{array}{l}\text { Income } 30 \mathrm{~K} \text { to } \\
50 \mathrm{~K}\end{array}$ & 0.125 & 0.330 & 0.098 & 0.297 & 0.071 & 0.256 \\
\hline $\begin{array}{l}\text { Income above } \\
50 \mathrm{~K}\end{array}$ & 0.045 & 0.208 & 0.033 & 0.180 & 0.036 & 0.186 \\
\hline White & 0.956 & 0.204 & 0.078 & 0.268 & 0.112 & 0.315 \\
\hline Subcontinent & 0.016 & 0.126 & 0.456 & 0.498 & 0.388 & 0.488 \\
\hline Other Asian & 0.001 & 0.027 & 0.057 & 0.232 & 0.078 & 0.268 \\
\hline Black & 0.010 & 0.100 & 0.265 & 0.441 & 0.202 & 0.402 \\
\hline Mixed race & 0.010 & 0.101 & 0.038 & 0.190 & 0.035 & 0.184 \\
\hline Chinese & 0.000 & 0.007 & 0.025 & 0.157 & 0.049 & 0.215 \\
\hline $\begin{array}{l}\text { Other } \\
\text { ethnicities }\end{array}$ & 0.006 & 0.079 & 0.080 & 0.272 & 0.136 & 0.343 \\
\hline Christian & 0.776 & 0.417 & 0.341 & 0.474 & 0.368 & 0.482 \\
\hline Budh & 0.002 & 0.045 & 0.016 & 0.127 & 0.037 & 0.189 \\
\hline Hindu & 0.002 & 0.039 & 0.135 & 0.341 & 0.152 & 0.359 \\
\hline Jewish & 0.003 & 0.052 & 0.003 & 0.051 & 0.001 & 0.035 \\
\hline Muslim & 0.017 & 0.129 & 0.385 & 0.487 & 0.330 & 0.470 \\
\hline Sikh & 0.001 & 0.037 & 0.053 & 0.225 & 0.027 & 0.162 \\
\hline Other religion & 0.019 & 0.138 & 0.026 & 0.159 & 0.021 & 0.144 \\
\hline No religion & 0.180 & 0.384 & 0.040 & 0.197 & 0.063 & 0.243 \\
\hline $\begin{array}{l}\text { Practicing } \\
\text { religion }\end{array}$ & 0.271 & 0.444 & 0.739 & 0.439 & 0.715 & 0.451 \\
\hline $\begin{array}{l}\text { Not practicing } \\
\text { religion }\end{array}$ & 0.729 & 0.444 & 0.261 & 0.439 & 0.285 & 0.451 \\
\hline Observations & 20,125 & Varial & $\begin{array}{l}8,399 \\
\text { vailable onl }\end{array}$ & 2009-2010 & 2,448 & \\
\hline Lost job & 0.059 & 0.236 & 0.055 & 0.228 & 0.088 & 0.284 \\
\hline $\begin{array}{l}\text { Drop in } \\
\text { income }\end{array}$ & 0.259 & 0.438 & 0.240 & 0.427 & 0.187 & 0.390 \\
\hline $\begin{array}{l}\text { Cutbacks in } \\
\text { luxuries }\end{array}$ & 0.390 & 0.488 & 0.307 & 0.461 & 0.213 & 0.410 \\
\hline $\begin{array}{l}\text { Cutbacks in } \\
\text { necessities }\end{array}$ & 0.332 & 0.471 & 0.334 & 0.472 & 0.228 & 0.420 \\
\hline Non-listed & 0.420 & 0.494 & 0.457 & 0.498 & 0.565 & 0.496 \\
\hline Observations & 7,068 & & 3119 & & 817 & \\
\hline
\end{tabular}


Table 2 shows that immigrants are on average younger than natives, and recent immigrants are, on average, the youngest group. Recent immigrants are more likely to be male, employed (and unemployed) and less likely to be out of the labour force than natives. Immigrants have, on average, lower incomes than natives, with recent immigrants having over a third of respondents in the lowest income group. Natives are mostly "White" by ethnicity. "Subcontinent" is the most dominant ethnicity in earlier and recent immigrants. Natives are mostly "Christian" by faith, whereas earlier immigrants are mostly "Muslim" and recent immigrants mostly "Christian".

\section{Empirical Strategy}

We begin by considering simple differences between natives, earlier and recent immigrants in their attitudes towards further immigration. These unconditional models provide a starting point for investigating differences in attitudes.

Subsequently, we control for socio-economic characteristics. The estimate of the coefficient attached to migrant status is now purged of observable differences in characteristics. This step enables us to see whether differences in socio-economic variables, such as labour market status, economic situation, or cultural background variables, such as religion, are responsible for the observed differences between natives and the various immigrant groups. It is difficult to make claims of causality with regards to these variables as at least some of them, such as practicing a religion, might very well be correlated with unobservables that also matter for a respondent's views on immigration policy.

Unless mentioned, our estimating equation for all the models is

$$
Y=\alpha+\beta^{\prime} I+\gamma^{\prime} X+\zeta^{\prime} Z+\varepsilon
$$

where $Y$ is the outcome variable, $\alpha$ is the intercept, $\beta$ is the coefficient vector for our key dummy variable $I$ that indicates the migration status of the respondent, $\gamma$ is the coefficient vector for the key independent variables $(X), \zeta$ is the coefficient vector for our additional controls such as regional dummies and age contained in $Z$, and $\varepsilon$ represents the error term.

Our key interest lies in the estimation of the $\beta$, coefficients attached to dummy variables indicating whether an individual is a native (the omitted category), an earlier immigrant, or a recent immigrant. Also of interest are coefficients on variables describing a respondent's labour market outcomes and economic status, as there is a strong public perception that opposition to immigration is primarily driven by labour market concerns.

We estimate our models using OLS, probit and ordered probit regressions to account for the binary nature of our main dichotomised outcome, as well as the ordinal nature of the underlying variable. For further analysis, we employ a Blinder-Oaxaca decomposition (Blinder, 1973; Oaxaca, 1973) to decompose the mean differences of the determinants of attitudes towards immigration for natives, earlier immigrants and recent immigrants, taken in pairs. The decomposition allows us to further investigate whether attitudes towards immigration are determined by differences in endowments, i. e., differences in the characteristics of natives and immigrants, or coefficients, i. e., the partial correlations between these characteristics and the outcome.

There are two reasons why the results should be seen as more descriptive than causal. Firstly, there may be unobservable characteristics, such as productivity or cultural upbringing, which contribute to views on immigration that may differ systematically between our groups. While we can use observable characteristics to overcome some of these problems, such as using education in the under 65-sample as a proxy for productivity, these are still imperfect controls.

Secondly, there are two potential sample selection problems as well. The first arises because some natives, who might be pro-immigration, may migrate abroad, meaning that they will not appear in the survey, potentially leading to an over-estimate of negative views towards immigration.

The second, and more important problem, relates to sample selection among immigrants. While our observation of recent immigrants may be largely representative of the population who have arrived in Great Britain, the same is not true of our earlier immigrant population. The problem we face is that some of the immigrants who initially arrived in Britain will return home or venture to other countries. The reasons for leaving can be diverse, although the most likely are that the period of work in Britain came to an end (or they found another job elsewhere), or that they did not find what they were looking for and decided to leave. Such behaviours mean that composition of recent immigrants might well be subtly different from that of earlier immigrants, leading to some issues when trying to generalise our results to the wider (future) population. 


\section{Results}

Panel A of Table 3 gives the results from the unconditional and conditional models for our preferred definition of immigrant and natives. The conditional models include controls for employment status, income level, age dummies, ethnicity, gender, religion, wave year and Government Office Region of residence. All models suggest that both immigrant groups are less opposed to further immigration than natives. Furthermore, the estimates for earlier immigrants are always closer to zero than the estimates for recent immigrants. Quantitatively, the unconditional models suggest that earlier immigrants are between 26 and 29 percentage points less likely to oppose immigration than natives, while the corresponding numbers for recent immigrants are between 41 and 49 percentage points. The coefficients are economically large and highly significant.

Table 3: Comparison of unconditional and conditional models.

\begin{tabular}{|c|c|c|c|c|c|c|c|c|}
\hline \multirow{3}{*}{$\begin{array}{l}\text { Reduce } \\
\text { immigra- } \\
\text { tion }\end{array}$} & (1) & & (3) & (4) & (5) & (6) & (7) & (8) \\
\hline & \multicolumn{4}{|c|}{ Unconditional models } & \multicolumn{4}{|c|}{ Conditional models } \\
\hline & OLS & $\begin{array}{l}\text { Probit } \\
\text { AME }\end{array}$ & $\begin{array}{l}\text { Probit co- } \\
\text { efficients }\end{array}$ & $\begin{array}{l}\text { Ordered } \\
\text { probit } \\
\text { Coeffi- } \\
\text { cients }\end{array}$ & OLS & $\begin{array}{l}\text { Probit } \\
\text { AME }\end{array}$ & $\begin{array}{l}\text { Probit co- } \\
\text { efficients }\end{array}$ & $\begin{array}{l}\text { Ordered } \\
\text { probit } \\
\text { Coeffi- } \\
\text { cients }\end{array}$ \\
\hline Panel A: & \multicolumn{8}{|c|}{ Base specification: Various estimation methods } \\
\hline $\begin{array}{l}\text { Recent } \\
\text { immi- } \\
\text { grants }\end{array}$ & $\begin{array}{c}-0.488^{*} \\
(0.010)\end{array}$ & $\begin{array}{c}-0.414^{*} \\
(0.008)\end{array}$ & $\begin{array}{c}-1.353^{*} \\
(0.028)\end{array}$ & $\begin{array}{l}-1.28^{*} \\
(0.022)\end{array}$ & $\begin{array}{c}-0.299^{*} \\
(0.015)\end{array}$ & $\begin{array}{c}-0.243^{*} \\
(0.012)\end{array}$ & $\begin{array}{c}-0.836^{*} \\
(0.041)\end{array}$ & $\begin{array}{c}-0.761^{*} \\
(0.033)\end{array}$ \\
\hline $\begin{array}{l}\text { Earlier } \\
\text { immi- } \\
\text { grants }\end{array}$ & $\begin{array}{c}-0.292^{*} \\
(0.006)\end{array}$ & $\begin{array}{c}-0.260^{*} \\
(0.005)\end{array}$ & $\begin{array}{c}-0.850^{*} \\
(0.017)\end{array}$ & $\begin{array}{c}-0.816^{*} \\
(0.015)\end{array}$ & $\begin{array}{c}-0.131^{*} \\
(0.012)\end{array}$ & $\begin{array}{c}-0.120^{*} \\
(0.010)\end{array}$ & $\begin{array}{c}-0.412^{*} \\
(0.035)\end{array}$ & $\begin{array}{c}-0.392 * \\
(0.029)\end{array}$ \\
\hline Constant & $\begin{array}{l}0.823^{*} \\
(0.003)\end{array}$ & & $\begin{array}{l}0.925^{*} \\
(0.010)\end{array}$ & & $\begin{array}{l}0.378^{*} \\
(0.015)\end{array}$ & & $\begin{array}{c}0.663 \\
(0.682)\end{array}$ & \\
\hline $\begin{array}{l}\text { Sample } \\
\text { size }\end{array}$ & 30,972 & 30,972 & 30,972 & 30,972 & 30,972 & 30,969 & 30,969 & 30,972 \\
\hline $\begin{array}{l}R^{2} / \text { Pseudo } \\
R^{2}\end{array}$ & 0.135 & & 0.108 & 0.064 & 0.181 & & 0.150 & 0.090 \\
\hline Panel B: & \multicolumn{8}{|c|}{ Estimates without constant } \\
\hline Natives & $\begin{array}{l}0.823^{*} \\
(0.003)\end{array}$ & & & & $\begin{array}{c}0.378^{*} \\
(0.015)\end{array}$ & & & \\
\hline $\begin{array}{l}\text { Recent } \\
\text { immi- } \\
\text { grants }\end{array}$ & $\begin{array}{l}0.334^{*} \\
(0.010)\end{array}$ & & & & $\begin{array}{l}0.079^{*} \\
(0.021)\end{array}$ & & & \\
\hline $\begin{array}{l}\text { Earlier } \\
\text { immi- } \\
\text { grants }\end{array}$ & $\begin{array}{l}0.530^{*} \\
(0.005)\end{array}$ & & & & $\begin{array}{c}0.248^{*} \\
(0.018)\end{array}$ & & & \\
\hline
\end{tabular}

* Notes: Conditional models control for employment status, wave year, age dummies, ethnicity, religion, practising religion or not, income, and region. Omitted category for migrant status dummy is "natives". Significance levels: " $10 \%$, ${ }^{* * *} 5 \%$, ${ }^{* * * *} 1 \%$. Robust standard errors are given in parentheses.

We obtain a similar pattern of results when using an ordered probit. In the conditional models, the estimates are nearly halved for all models. Earlier immigrants are now between 12 and 13 percentage points less likely to oppose further immigration than natives, while recent immigrants are between 24 and 30 percentage points less likely, as presented in column (5) and (6) of Table 3. However, the differences between the three groups remain large and statistically significant.

The bottom panel of Table 3 presents estimates for a model, without a constant, that includes dummies for natives, earlier and recent immigrants. In the unconditional models, the estimates correspond to the fraction of respondents in each of the groups who are opposed to further immigration. In the conditional models, these dummies can be interpreted as residual differences after the effects of the other observable variables have been taken out. Including these reduces the residual share of respondents who are opposed to immigration in each group. Residual shares are still large, however, suggesting that the opposition to immigration is not just driven by the included RHS variables. The results for earlier immigrants are between those of natives and recent immigrants. We conduct F-tests to check for the equality of the coefficients and find that the coefficients of the three groups are significantly different from each other. Additionally, confidence intervals around the coefficients from the three groups do not overlap, again suggesting a significant difference. From these results, it is clear 
that support for further immigration differs widely between the three groups and that earlier immigrants hold views that, on average, fall between the views of natives and recent immigrants.

Table 4 explores the impact of using alternative definitions of immigrants or natives as described in Section 2, again for conditional and unconditional models. Columns (1) and (2) are replicated from Table 3, while columns (3) and (4) and (5) and (6) rely on alternative definitions. As we can see the results are fairly independent of these choices.

Table 4: Comparison of immigrant definitions.

\begin{tabular}{|c|c|c|c|c|c|c|}
\hline \multirow[b]{2}{*}{ Panel A: } & \multicolumn{2}{|c|}{$\begin{array}{l}\text { Narrow natives vs. narrow } \\
\text { immigrants (Table 3) }\end{array}$} & \multicolumn{2}{|c|}{$\begin{array}{l}\text { UK born vs. narrow } \\
\text { immigrants }\end{array}$} & \multicolumn{2}{|c|}{$\begin{array}{l}\text { UK born vs. UK born with } \\
\text { immigration background vs. } \\
\text { foreign born }\end{array}$} \\
\hline & (1) & (2) & (3) & (4) & (5) & (6) \\
\hline Recent & $-0.488^{*}$ & $-0.299^{*}$ & $-0.452^{*}$ & $-0.290^{*}$ & $-0.488^{*}$ & $-0.308^{*}$ \\
\hline immigrants & $(0.010)$ & $(0.015)$ & $(0.010)$ & $(0.012)$ & $(0.010)$ & $(0.013)$ \\
\hline Earlier & $-0.292^{*}$ & $-0.131^{*}$ & $-0.256^{*}$ & $-0.123^{*}$ & $-0.285^{*}$ & $-0.138^{*}$ \\
\hline immigrants & $(0.006)$ & $(0.012)$ & $(0.006)$ & $(0.008)$ & $(0.006)$ & $(0.010)$ \\
\hline Natives with & & & & & $-0.176^{*}$ & $-0.031^{*}$ \\
\hline immigration & & & & & $(0.007)$ & $(0.009)$ \\
\hline background & & & & & & \\
\hline Sample size & 30,972 & 30,972 & 36,205 & 36,205 & 36,652 & 36,652 \\
\hline Controls & No & Yes & No & Yes & No & Yes \\
\hline
\end{tabular}

* Notes: Columns (1) and (2): Natives are individuals born in the UK to UK-born parents (base category). Immigrants are foreign-born individuals with foreign born parents.Columns (3) and (4): Natives are individuals born in the UK regardless of parents' birth (base category). Immigrants are foreign-born individuals with foreign born parents.Columns (5) and (6): Natives are individuals born in the UK to UK-born parents (base category). Natives with immigration background are either individuals born in the UK with at least one parent born outside of the UK or overseas-born individuals whose parents were both born in the UK. Immigrants are all foreign-born individual, regardless of parents' birth. ${ }^{* * * *}$ Controls are identical to those used in Table 3 . Significance levels: " $10 \%$,

${ }^{* *} 5 \%,{ }^{* * *} 1 \%$. Robust standard errors are given in parentheses.

In Table 5, we present separate models for natives, earlier and recent immigrants. These suggest that, by and large, and with the exception of earlier immigrants who are out of the labour force, none of the labour market dummies are significant. It is interesting to note that the significant coefficient for "out of the labour force" suggests that these respondents are, if anything, more in favour of further immigration than employed respondents. Based on these results, it appears that labour market status is largely unrelated to anti-immigration views for any of the groups. These findings are in line with the findings of Dustmann and Preston (2007) and Card, Dustmann, and Preston (2012) who also find that labour market concerns are not important in determining natives' views towards immigration. Furthermore, a range of studies find that welfare concerns or non-economic concerns, such as a loss of identity are more important than the labour market concerns. ${ }^{9}$

Table 5: Coefficients of main controls for each respondent category (2007-2010).

\begin{tabular}{lcccc}
\hline Reduce immigration & Natives & $\begin{array}{c}\text { OLS } \\
\text { Earlier immigrants }\end{array}$ & Recent immigrants \\
\hline Recent Immigrants & $-0.299^{*}$ & & & \\
& $(0.015)$ & & & \\
Earlier immigrants & $-0.131^{*}$ & & & $0.046^{*}$ \\
Female & $(0.012)$ & & & $(0.021)$ \\
& 0.007 & -0.007 & $(0.012)$ & -0.024 \\
Out of labour force & $(0.005)$ & $(0.006)$ & $-0.044^{*}$ & $(0.030)$ \\
Self-employed & $-0.021^{*}$ & -0.003 & $(0.017)$ & -0.006 \\
& $(0.008)$ & $(0.009)$ & -0.013 & $(0.050)$ \\
Unemployed & 0.001 & 0.010 & $(0.021)$ & 0.016 \\
Income below 5K & $(0.010)$ & $(0.011)$ & -0.008 & $(0.030)$ \\
Income 5K to 10K & 0.003 & 0.007 & $(0.017)$ & $-0.100^{*}$ \\
Income 15K to 20K & $(0.008)$ & $(0.009)$ & 0.004 & $(0.032)$ \\
& -0.010 & -0.006 & $(0.018)$ & $-0.088^{*}$
\end{tabular}




\begin{tabular}{|c|c|c|c|c|}
\hline Income $20 \mathrm{~K}$ to $30 \mathrm{~K}$ & $\begin{array}{c}-0.038^{*} \\
(0.009)\end{array}$ & $\begin{array}{c}-0.046^{*} \\
(0.010)\end{array}$ & $\begin{array}{c}-0.022 \\
(0.019)\end{array}$ & $\begin{array}{c}-0.088^{*} \\
(0.037)\end{array}$ \\
\hline \multirow[t]{2}{*}{ Income $30 \mathrm{~K}$ to $50 \mathrm{~K}$} & $-0.086^{*}$ & $-0.092^{*}$ & $-0.066^{*}$ & $-0.150^{*}$ \\
\hline & $(0.010)$ & $(0.011)$ & $(0.022)$ & $(0.044)$ \\
\hline \multirow[t]{2}{*}{ Income above $50 \mathrm{~K}$} & $-0.128^{*}$ & $-0.142^{*}$ & $-0.079^{*}$ & $-0.195^{*}$ \\
\hline & $(0.014)$ & $(0.017)$ & $(0.034)$ & $(0.055)$ \\
\hline \multirow[t]{2}{*}{ Subcontinent } & -0.018 & 0.045 & 0.025 & 0.039 \\
\hline & $(0.017)$ & $(0.051)$ & $(0.025)$ & $(0.043)$ \\
\hline \multirow[t]{2}{*}{ Other Asian } & $-0.073^{*}$ & 0.139 & -0.022 & -0.040 \\
\hline & $(0.023)$ & $(0.127)$ & $(0.031)$ & $(0.049)$ \\
\hline \multirow[t]{2}{*}{ Black } & $-0.158^{*}$ & $-0.273^{*}$ & $-0.098^{*}$ & $-0.112^{*}$ \\
\hline & $(0.015)$ & $(0.035)$ & $(0.022)$ & $(0.039)$ \\
\hline \multirow[t]{2}{*}{ Mixed race } & $-0.087^{*}$ & $-0.073^{*}$ & $-0.061^{*}$ & -0.009 \\
\hline & $(0.021)$ & $(0.033)$ & $(0.033)$ & $(0.060)$ \\
\hline \multirow[t]{2}{*}{ Chinese } & $-0.094^{*}$ & $0.606^{*}$ & 0.014 & -0.071 \\
\hline & $(0.029)$ & $(0.053)$ & $(0.040)$ & $(0.057)$ \\
\hline \multirow[t]{2}{*}{ Other ethnicities } & $-0.051^{*}$ & -0.015 & -0.013 & 0.021 \\
\hline & $(0.018)$ & $(0.038)$ & $(0.028)$ & $(0.043)$ \\
\hline \multirow[t]{2}{*}{ Budh } & $-0.092^{*}$ & -0.053 & $-0.154^{*}$ & -0.002 \\
\hline & $(0.030)$ & $(0.067)$ & $(0.043)$ & $(0.057)$ \\
\hline \multirow[t]{2}{*}{ Hindu } & -0.011 & $-0.258^{*}$ & 0.014 & -0.054 \\
\hline & $(0.018)$ & $(0.097)$ & $(0.022)$ & $(0.038)$ \\
\hline \multirow[t]{2}{*}{ Jewish } & $-0.156^{*}$ & $-0.138^{*}$ & $-0.210^{*}$ & 0.029 \\
\hline & $(0.054)$ & $(0.064)$ & $(0.107)$ & $(0.275)$ \\
\hline \multirow[t]{2}{*}{ Muslim } & $-0.109^{*}$ & $-0.314^{*}$ & $-0.075^{*}$ & -0.012 \\
\hline & $(0.014)$ & $(0.048)$ & $(0.018)$ & $(0.030)$ \\
\hline \multirow[t]{2}{*}{ Sikh } & 0.012 & $-0.188^{*}$ & 0.010 & 0.104 \\
\hline & $(0.025)$ & $(0.100)$ & $(0.029)$ & $(0.067)$ \\
\hline \multirow[t]{2}{*}{ Other religion } & 0.000 & -0.016 & 0.013 & 0.086 \\
\hline & $(0.017)$ & $(0.020)$ & $(0.034)$ & $(0.073)$ \\
\hline \multirow[t]{2}{*}{ No religion } & $-0.075^{*}$ & $-0.081^{*}$ & $-0.141^{*}$ & -0.032 \\
\hline & $(0.008)$ & $(0.008)$ & $(0.031)$ & $(0.049)$ \\
\hline \multirow[t]{2}{*}{ Practicing religion } & $-0.055^{*}$ & $-0.050^{*}$ & $-0.058^{*}$ & -0.023 \\
\hline & $(0.006)$ & $(0.006)$ & $(0.013)$ & $(0.025)$ \\
\hline \multirow[t]{2}{*}{ Constant } & $0.378^{*}$ & $1.120^{*}$ & $-0.088^{*}$ & 0.086 \\
\hline & $(0.015)$ & $(0.016)$ & $(0.033)$ & $(0.068)$ \\
\hline Sample size & 30,972 & 20,125 & 8,399 & 2,448 \\
\hline$R^{2}$ & 0.181 & 0.065 & 0.075 & 0.059 \\
\hline
\end{tabular}

* Notes: All models control for: wave year, age dummies, and region. Omitted category for migrant status, employment status, income dummies, ethnicity, religion and practising religion is natives, employed and income $10 \mathrm{~K}$ to $15 \mathrm{~K}$, white, Christian, and not practising religion respectively.Significance levels: " $10 \%$, ${ }_{*}{ }^{\circ} \%$, ${ }^{* * * *} 1 \%$. Robust standard errors are given in parentheses.

Income dummies are used to analyse the impact of economic status on opposition to further immigration. It is interesting to note that for natives and earlier immigrants a clear gradient emerges, presented in Figure 1. Natives and immigrants with higher income are more likely to be in support of further immigration. For recent immigrants the pattern appears to be less clear. Relative to individuals earning between $£ 10 \mathrm{k}$ and $£ 15 \mathrm{k}$, individuals with lower incomes are between 8 and 1 percentage points less likely to oppose immigration, while respondents with higher income are also less opposed towards further immigration, resulting in an inverted Ushaped relationship between income and opposition to immigration. Potential explanations for this somewhat unexpected result at low incomes could be the role of non-monetary motives such as family reunification, or the desire for individuals to see more immigration from their home country, which may be stronger for recent immigrants than for earlier immigrants. 


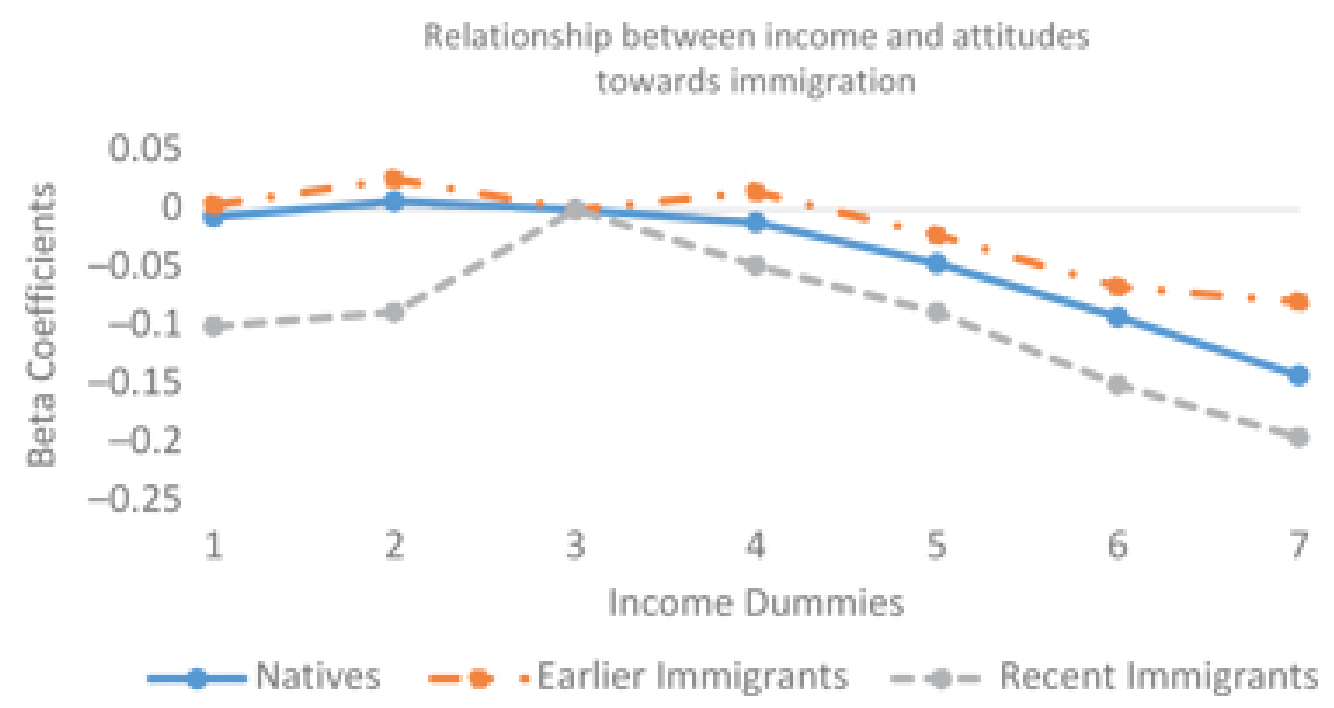

Figure 1: Comparison of the relationship between income and attitudes towards immigration for natives, earlier immigrants and recent immigrants.

In terms of the other control variables, Table 5 suggests some gender differences among the two immigrant groups but not among natives. There are also some differences across the various ethnic groups. ${ }^{10} \mathrm{While} \mathrm{diffi-}^{-}$ cult to interpret, these could principally point towards differences by region or country of origin. Finally, the religion dummies suggest that more sympathy towards further immigration among non-Christian faiths.

Finally, we look at the effect of economic shocks experienced in the previous year. Our results, shown in Table 6, suggest that experience in the previous period of a job loss, a drop in income, having to cut back expenses or having to cut back expenses on both necessities and luxuries are associated with a stronger opposition to further immigration, even when controlling for current circumstances (see, Gang, Rivera-Batiz, and Yun (2013) for similar findings).

Table 6: Wave 2009-2010 models for each respondent category controlled for financial worry dummies.

\begin{tabular}{|c|c|c|c|c|}
\hline \multirow[t]{2}{*}{ Reduce immigration } & \multicolumn{4}{|c|}{ OLS } \\
\hline & Pooled & Natives & Earlier immigrants & Recent immigrants \\
\hline Recent immigrants & $\begin{array}{c}-0.292^{*} \\
(0.023)\end{array}$ & & & \\
\hline Earlier immigrants & $\begin{array}{c}-0.111^{*} \\
(0.019)\end{array}$ & & & \\
\hline Lost job & $\begin{array}{l}0.038^{*} \\
(0.017)\end{array}$ & $\begin{array}{l}0.045^{*} \\
(0.019)\end{array}$ & $\begin{array}{c}0.021 \\
(0.041)\end{array}$ & $\begin{array}{c}0.052 \\
(0.066)\end{array}$ \\
\hline Drop in income & $\begin{array}{l}0.032^{*} \\
(0.010)\end{array}$ & $\begin{array}{l}0.021^{*} \\
(0.011)\end{array}$ & $\begin{array}{l}0.044^{*} \\
(0.022)\end{array}$ & $\begin{array}{c}0.074 \\
(0.048)\end{array}$ \\
\hline Cutbacks in luxuries & $\begin{array}{l}0.027^{*} \\
(0.010)\end{array}$ & $\begin{array}{c}0.002 \\
(0.011)\end{array}$ & $\begin{array}{l}0.070^{*} \\
(0.022)\end{array}$ & $\begin{array}{c}0.017 \\
(0.046)\end{array}$ \\
\hline $\begin{array}{l}\text { Cutbacks in } \\
\text { necessities }\end{array}$ & $\begin{array}{l}0.028^{*} \\
(0.010)\end{array}$ & $\begin{array}{l}0.023^{*} \\
(0.011)\end{array}$ & $\begin{array}{l}0.025 \\
(0.021)\end{array}$ & $\begin{array}{l}0.100^{*} \\
(0.045)\end{array}$ \\
\hline Out of labour force & $\begin{array}{c}-0.024^{*} \\
(0.013)\end{array}$ & $\begin{array}{l}-0.010 \\
(0.015)\end{array}$ & $\begin{array}{l}-0.013 \\
(0.026)\end{array}$ & $\begin{array}{c}-0.113^{*} \\
(0.045)\end{array}$ \\
\hline Self-employed & $\begin{array}{l}-0.009 \\
(0.017)\end{array}$ & $\begin{array}{c}0.001 \\
(0.019)\end{array}$ & $\begin{array}{l}-0.013 \\
(0.036)\end{array}$ & $\begin{array}{l}-0.099 \\
(0.085)\end{array}$ \\
\hline Unemployed & $\begin{array}{l}-0.005 \\
(0.013)\end{array}$ & $\begin{array}{c}0.004 \\
(0.015)\end{array}$ & $\begin{array}{l}-0.022 \\
(0.029)\end{array}$ & $\begin{array}{c}0.046 \\
(0.050)\end{array}$ \\
\hline Female & $\begin{array}{c}0.000 \\
(0.009)\end{array}$ & $\begin{array}{l}-0.003 \\
(0.010)\end{array}$ & $\begin{array}{l}-0.002 \\
(0.019)\end{array}$ & $\begin{array}{c}0.036 \\
(0.036)\end{array}$ \\
\hline Income below $5 \mathrm{~K}$ & $\begin{array}{l}-0.001 \\
(0.013)\end{array}$ & $\begin{array}{l}-0.010 \\
(0.015)\end{array}$ & $\begin{array}{c}0.038 \\
(0.028)\end{array}$ & $\begin{array}{c}-0.111^{*} \\
(0.052)\end{array}$ \\
\hline Income $5 \mathrm{~K}$ to $10 \mathrm{~K}$ & $\begin{array}{c}0.016 \\
(0.013)\end{array}$ & $\begin{array}{l}-0.005 \\
(0.014)\end{array}$ & $\begin{array}{l}0.067^{*} \\
(0.029)\end{array}$ & $\begin{array}{l}-0.080 \\
(0.058)\end{array}$ \\
\hline Income $15 \mathrm{~K}$ to $20 \mathrm{~K}$ & $\begin{array}{c}0.005 \\
(0.015)\end{array}$ & $\begin{array}{l}-0.022 \\
(0.017)\end{array}$ & $\begin{array}{l}0.075^{*} \\
(0.035)\end{array}$ & $\begin{array}{l}-0.059 \\
(0.078)\end{array}$ \\
\hline Income $20 \mathrm{~K}$ to $30 \mathrm{~K}$ & $\begin{array}{l}-0.015 \\
(0.014)\end{array}$ & $\begin{array}{c}-0.028^{*} \\
(0.016)\end{array}$ & $\begin{array}{c}0.025 \\
(0.032)\end{array}$ & $\begin{array}{c}-0.133^{*} \\
(0.066)\end{array}$ \\
\hline
\end{tabular}




\begin{tabular}{|c|c|c|c|c|}
\hline Income $30 \mathrm{~K}$ to $50 \mathrm{~K}$ & $\begin{array}{c}-0.069^{*} \\
(0.017)\end{array}$ & $\begin{array}{c}-0.087^{*} \\
(0.019)\end{array}$ & $\begin{array}{l}-0.032 \\
(0.037)\end{array}$ & $\begin{array}{l}-0.070 \\
(0.076)\end{array}$ \\
\hline \multirow[t]{2}{*}{ Income above $50 \mathrm{~K}$} & $-0.088^{*}$ & $-0.112^{*}$ & -0.026 & -0.155 \\
\hline & $(0.025)$ & $(0.028)$ & $(0.057)$ & $(0.107)$ \\
\hline \multirow[t]{2}{*}{ Subcontinent } & -0.024 & 0.017 & 0.029 & $0.161^{*}$ \\
\hline & $(0.026)$ & $(0.060)$ & $(0.040)$ & $(0.078)$ \\
\hline \multirow[t]{2}{*}{ Other Asian } & $-0.108^{*}$ & 0.122 & -0.071 & 0.061 \\
\hline & $(0.036)$ & $(0.139)$ & $(0.050)$ & $(0.087)$ \\
\hline \multirow[t]{2}{*}{ Black } & $-0.189 *$ & $-0.265^{*}$ & $-0.123^{*}$ & -0.050 \\
\hline & $(0.023)$ & $(0.051)$ & $(0.038)$ & $(0.075)$ \\
\hline \multirow[t]{2}{*}{ Mixed race } & -0.052 & -0.013 & -0.021 & 0.041 \\
\hline & $(0.036)$ & $(0.051)$ & $(0.061)$ & $(0.134)$ \\
\hline \multirow[t]{2}{*}{ Chinese } & $-0.128^{*}$ & & 0.049 & -0.112 \\
\hline & $(0.048)$ & & $(0.069)$ & $(0.087)$ \\
\hline \multirow[t]{2}{*}{ Other ethnicities } & $-0.099^{*}$ & -0.102 & -0.016 & 0.031 \\
\hline & $(0.031)$ & $(0.089)$ & $(0.047)$ & $(0.077)$ \\
\hline \multirow[t]{2}{*}{ Budh } & -0.039 & 0.023 & -0.056 & 0.058 \\
\hline & $(0.054)$ & $(0.102)$ & $(0.085)$ & $(0.094)$ \\
\hline \multirow[t]{2}{*}{ Hindu } & 0.015 & $-0.190^{*}$ & 0.026 & 0.061 \\
\hline & $(0.031)$ & $(0.113)$ & $(0.038)$ & $(0.071)$ \\
\hline \multirow[t]{2}{*}{ Jewish } & $-0.206^{*}$ & -0.124 & $-0.340^{*}$ & $-0.356^{*}$ \\
\hline & $(0.096)$ & $(0.112)$ & $(0.187)$ & $(0.107)$ \\
\hline \multirow[t]{2}{*}{ Muslim } & $-0.109^{*}$ & $-0.257^{*}$ & $-0.077^{*}$ & 0.017 \\
\hline & $(0.021)$ & $(0.059)$ & $(0.027)$ & $(0.052)$ \\
\hline \multirow[t]{2}{*}{ Sikh } & -0.015 & -0.138 & -0.017 & 0.039 \\
\hline & $(0.042)$ & $(0.115)$ & $(0.050)$ & $(0.122)$ \\
\hline \multirow[t]{2}{*}{ Other religion } & 0.010 & -0.018 & 0.030 & 0.220 \\
\hline & $(0.033)$ & $(0.039)$ & $(0.064)$ & $(0.149)$ \\
\hline \multirow[t]{2}{*}{ No religion } & $-0.054^{*}$ & $-0.058^{*}$ & $-0.179^{*}$ & 0.104 \\
\hline & $(0.012)$ & $(0.013)$ & $(0.054)$ & $(0.090)$ \\
\hline \multirow[t]{2}{*}{ Practicing religion } & $-0.051^{*}$ & $-0.047^{*}$ & -0.038 & -0.052 \\
\hline & $(0.010)$ & $(0.011)$ & $(0.023)$ & $(0.044)$ \\
\hline \multirow[t]{2}{*}{ Constant } & $0.830^{*}$ & $0.951^{*}$ & $0.984^{*}$ & -0.152 \\
\hline & $(0.135)$ & $(0.037)$ & $(0.055)$ & $(0.106)$ \\
\hline Sample size & 11,004 & 7,068 & 3,119 & 817 \\
\hline$R^{2}$ & 0.195 & 0.089 & 0.100 & 0.140 \\
\hline
\end{tabular}

* Note: All models control for: wave year, age dummies, and region. Omitted category for financial worry dummies is "not reporting any worry".

${ }^{* *}$ Significance levels: ${ }^{*} 10 \%,{ }^{* *} 5 \%$, *** $1 \%$. Robust standard errors are given in parentheses.

For natives, job loss is associated with a 4 percentage points increase in opposition to further immigration, while drops in income and cutbacks in necessities are associated with a 2 percentage points increase. For earlier immigrants, drops in income and cutbacks in luxuries appear to matter most, while job loss and cutbacks in necessities appear to be less important. Finally, the point estimates for recent immigrants suggest that they react more strongly to job losses, drops in income and, in particular, cutbacks in necessities than the other groups. These results suggest that changes in economic status in earlier periods, such as drops in income or job loss, matter for people's views on immigration, even when holding the current levels of these variables constant.

On the whole, our results support our earlier suggestion that earlier immigrants appear to hold views closer to those of natives than to recent immigrants. ${ }^{11}$

Table 7 presents the results from Blinder-Oaxaca-decompositions for the various group pairings, (a) natives and earlier immigrants, (b) natives and recent immigrants and (c) earlier immigrants and recent immigrants. The mean difference in the fraction of respondents who are opposed to immigration between the earlier mentioned three groups (a), (b) and (c) is 29.2, 48.8 and 19.6 percentage points, with a $1 \%$ level of significance. The "endowments effect" is only significant for comparison (a) with a point estimate of 11.2, suggesting that about $40 \%$ of the differential can be explained by differences in characteristics. For comparisons (b) and (c) only the "coefficients effect" is significant, with point estimates of 28.3 and 20.1 percentage points. It shows that the recent immigrants would be 28.3 (20.1) percentage points more opposed to immigration if the coefficients of natives (earlier immigrants) were applied to recent immigrants' characteristics. These results suggest that for these comparisons it is not differences in the characteristics between the groups that matters but the fact that the marginal effects are different. The fact that the results are similar when comparing both natives and earlier 
immigrants to recent immigrants again confirms the view that natives and earlier immigrants are increasingly similar.

Table 7: Oaxaca decomposition of the determinants of attitudes towards immigration for natives, earlier immigrants and recent immigrants.

\begin{tabular}{cccc}
\hline Reduce immigration & $\begin{array}{c}\text { Natives/earlier } \\
\text { immigrants }\end{array}$ & $\begin{array}{c}\text { Natives /recent } \\
\text { immigrants }\end{array}$ & $\begin{array}{c}\text { Earlier immigrants /recent } \\
\text { immigrants }\end{array}$ \\
\hline Group 1 & $0.823^{*}$ & $0.823^{*}$ & $0.530^{*}$ \\
(Natives/Natives/Earlier) & $(0.003)$ & $(0.003)$ & $(0.005)$ \\
Group 2 & $0.530^{*}$ & $0.334^{*}$ & $0.334^{*}$ \\
(Earlier/Recent/Recent) & $(0.005)$ & $(0.010)$ & $(0.010)$ \\
Difference & $0.292^{*}$ & $0.488^{*}$ & $0.196^{*}$ \\
Endowments & $(0.006)$ & $(0.010)$ & $(0.011)$ \\
Coefficients & $0.112^{*}$ & 0.033 & -0.006 \\
Interaction & $(0.018)$ & $(0.029)$ & $(0.007)$ \\
& 0.031 & $0.283^{*}$ & $0.201^{*}$ \\
\hline
\end{tabular}

* Notes: All models control for: gender, employment status, ethnicity, religion, practising religion or not, income, wave year and region. Significance levels:

${ }^{*} 10 \%,{ }^{* * *} 5 \%$, ${ }^{* * * *} 1 \%$. Robust standard errors are given in parentheses.

\section{Discussion and Conclusion}

Much of the empirical literature has focused on the impact of immigration on local labour markets. ${ }^{12}$ The literature investigating the views of natives towards further immigration is also growing rapidly. Whereas, views of immigrants towards immigration have gained little attention.

This paper is a new addition to the sparse literature investigating how immigrants view further immigration, and how these views may vary between natives, earlier and more recent immigrants. The main finding of this research is that there is heterogeneity in the attitudes of immigrants towards immigration, with recent immigrants being less opposed to immigration than earlier immigrants.

The results for earlier immigrants consistently lie between those of natives and recent immigrants. There are essentially two explanations why earlier immigrants are more similar to natives than recent ones. The first is that as time passes immigrants integrate into British society. Secondly, it could be the case that only those immigrants who are similar to natives stay in the country, while other immigrants, with differing views, leave. The first explanation is supported by the findings of Manning and Roy (2010) concerning cultural assimilation; immigrants appear to become more similar to natives the longer they have been in the country (see also, Gordon, 1964; Heath et al., 2013). Manning and Roy (2010) find that immigrants integrate into the British culture very easily.

The second explanation is essentially self-selection but the limited available information in the data, in particular the fact that we do not observe immigrants who have left, does not allow this to be tested. It could also be the case that people who left the UK in fact did not want to leave the UK but they had to leave because of the visa restrictions.

This study does not find any strong consistent evidence that the anti-immigration views of natives, earlier and recent immigrants towards further immigration can be attributed to labour market outcomes. Even if the earlier immigrants and recent immigrants compete in the labour market, as suggested by the findings of Ottaviano and Peri (2012) and Dustmann, Frattini, and Preston (2013), there is no strong evidence that the current employment status affects views towards further immigration.

Results regarding the income of natives and earlier immigrants suggest a clear gradient for respondents, with higher income favouring further immigration, whereas there is some evidence for an inverted U-shape for recent immigrants. A potential explanation for this result is that low-income recent immigrants may have concerns that family reunification may be made harder by tougher immigration laws, and these worries may overwhelm other concerns.

We further find evidence in all three groups that economic shocks, such as job loss or drops in income in a previous period matter, even when holding current employment status and the level of income constant. This 
finding is in line with the previous literature (see, for example, Gang, Rivera-Batiz \& Yun, 2013; and MalchowMoller et al. 2008). This result suggests that people might be blaming immigrants for adverse shocks, regardless of whether they recover from the respective shock.

Overall, this research suggests (a) that earlier immigrants and natives share more similar views towards further immigration than earlier and recent immigrants, (b) that employment status does not play a large role in explaining anti-immigration views, (c) income matters, even though the exact effects differ at low incomes between recent immigrants, natives and earlier immigrants, and (d) that economic shocks tend to be associated with more anti-immigration views.

These results are important in helping us understand some of the drivers behind anti-immigration views - which played a large role both in the 2016 UK referendum on EU membership and the 2016 US presidential election. Importantly, the fact that both earlier and more recent immigrants also oppose further immigration, although to a lesser extent than natives, suggests that this opposition cannot simply be explained as xenophobia.

\section{Acknowledgement}

Muhammad Waqas would like to acknowledge the funding from the Peter and Norah Lomas PhD Scholarship in Economics. All analyses used Stata 13. Do-files and data are available from the authors on request. All views are those of the authors.

\section{Notes}

${ }^{1}$ For a critical review of immigration related theories and immigration related literature see, Ceobanu and Escandell (2010) and Hainmueller and Hopkins (2014a). Among others, some of the recent research papers on views of natives towards further immigration using data from the European Social Survey include, Bridges and Mateut (2014), Malchow-Moller et al. (2009), and Malchow-Moller et al. (2008)) , Markaki and Longhi (2013), Ortega and Polavieja (2012), and O'Connell (2011).

${ }^{2}$ According to the Office for National Statistics' quarterly report published in February, 2012, 593,000 immigrants came to the UK in between June 2010 and June 2011 (ONS 2012). In June 2009 to June 2010, 582,000 immigrants came to the UK and the number of immigrants coming to UK has been around this level since 2004. In the labour market, 690,000 National Insurance Numbers were issued to people having any nationality other than British in the year up to September, 2011. This allocation of National Insurance Numbers was an increase of $11 \%$ relative to the previous year.

${ }^{3}$ Much of the previous economics literature that this paper contributes to, refers to "attitudes" rather than views. In the wider social sciences, "attitudes" are often taken to represent a deeper psychological consideration that cannot be identified from the questions normally used in the research in economics on attitudes. For the purpose of this paper the terms "attitudes" and "views" are used interchangeably assuming that, even if they are not identical, they are highly correlated.

${ }^{4}$ Most of the literature investigate natives' views towards further immigration and find evidence for a strong positive relation between education and support for (further) immigration see, for example, Card, Dustmann, and Preston (2005), Constant and Zimmermann (2013), Dustmann and Preston (2004), and Gang, Rivera-Batiz, and Yun (2013) for Europe, Dustmann and Preston (2001) for England, Vervoort (2012) for Netherlands, Bauer, Lofstrom, and Zimmermann (2000) , for OECD countries and Citrin et al. (1997), Espenshade and Hempstead (1996), Hainmueller and Hopkins (2014b), and Scheve and Slaughter (2001) for USA.

${ }^{5}$ Although this may be a consequence on the "lump of labour" fallacy, i. e., individuals' perception that there is fixed number of jobs in the economy that can be distributed between immigrants and natives, whereas, new jobs are created as a natural reaction to the expansion and growth of businesses and economy on the influx of new immigrants.

${ }^{6}$ See the special issue of the Journal of the European Economic Association (Borjas, Grogger \& Hanson, 2012; Card, 2012; Card, Dustmann \& Preston, 2012; Dustmann \& Preston, 2012; Manacorda, Manning \& Wadsworth, 2012; Ottaviano \& Peri, 2012) for a comprehensive discussion of the current state of the literature.

${ }^{7}$ It should be noted that integration and assimilation convey different meanings. Integration means to integrate own preferences in the cultural setting of the destination country, whereas, assimilation indicates replacement of own preferences with those of the country of destination (see, Berry (1997)). This paper uses the term integration for the sake of its own findings and analysis, however, the term assimilation is used to connect this paper with the assimilation process presented in the work of Manning and Roy (2010).

${ }^{8}$ The survey has been collected since 2001. Initially it was a biennial survey conducted by the Home Office, in 2006 it fell under the auspices of the Communities and Local Government department now the Department for Communities and Local Government. From 2007 onwards the survey has been conducted annually, with data collection taking place each quarter. The publicly available data for this period combines four quarters, giving surveys for 2007-2008, 2008-2009, 2009-2010, and 2010-2011.

${ }^{9}$ Card, Dustmann, and Preston (2012), Hainmueller and Hiscox (2007), and Rustenbach (2010), for Europe, Dustmann and Preston (2007) , for England, Heath et al. (2013) for Britain, Fetzer (2011) for U.S. and Europe, Bakker and Dekker (2012) for Amsterdam, Facchini, Mayda, and Mendola (2013) for South Africa, Stanley, Stanley, and Hensher (2012) for Australia, Nielsen, Paritski, and Smyth (2012) for a small Italian town, and Mayda (2006) for developed and developing countries emphasize the importance of social interaction, social capital, sense of society, interpersonal trust and compositional concerns.

${ }^{10}$ We conducted a robustness check to test whether the estimates for natives in Table 5 are derived by the "actual natives" (natives with white ethnicity) or by the earlier generations of immigrants whose parents were born in the UK too and our definition of natives characterized them as natives. After excluding 880 cases of natives with other than white ethnicity and running the same regressions again, we still found the similar estimates. It shows that estimates are driven by actual natives with white ethnicity.

${ }^{11}$ As a robustness check, all the respondents who responded with "remain the same" to the outcome question are dropped from the data and all the models are rerun. Results from these regressions remain fairly similar. If anything, the similarities between earlier immigrants and natives increased. 


\begin{abstract}
${ }^{12}$ For reviews of the literature on the economic impact of immigration see Borjas (1994), Friedberg and Hunt (1995), LaLonde and Topel (1996), and Borjas (1999). Contrary to Borjas (2003) most findings suggest that immigration does not have any considerable adverse effect on local labour markets, see Card (1990), Altonji and Card (1991), Kuhn and Wooton (1991), LaLonde and Topel (1991), and Card (2001) for the US, Dustmann, Fabbri, and Preston (2003) and Dustmann, Fabbri, and Preston (2005) for the UK, Haisken-DeNew and Zimmermann (1994), Pischke and Velling (1997), and Haisken-DeNew and Zimmermann (1999) for Germany, Winter-Ebmer and Zweimuller (1996) and Winter-Ebmer and Zweimuller (1999) for Austria, Hunt (1992) for France, Carrington and Lima (1996) for Portugal, and Angrist and Kugler (2003) for Western Europe as whole.
\end{abstract}

\title{
References
}

Altonji, J. G., and D. Card. 1991. "The Effects of Immigration on the Labor Market Outcomes of Less-Skilled Natives." In Immigration, Trade and Labor., edited by J.M. Abowd, and R.B. Freeman, 201-234. Chicago: University of Chicago Press.

Angrist, J. D., and A. D. Kugler. 2003. “Protective or Counter-Productive? Labour Market Institutions and the Effect of Immigration on EU Natives." Economic Journal 113 (488):. F302-F331.

Bakker, L., and K. Dekker. 2012. “Social Trust in Urban Neighbourhoods: The Effect of Relative Ethnic Group Position.” Urban Studies 49 (10): 2031-2047.

Bauer, T. K., M. Lofstrom, and K. F. Zimmermann. 2000. “Immigration Policy, Assimilation of Immigrants and Natives' Sentiments Towards Immigrants: Evidence from 12 Oecd-Countries." Swedish Economic Policy Review 7 (2): 11-53.

Bell, B., F. Fasani, and S. Machin. 2013. "Crime and Immigration: Evidence from Large Immigrant Waves in the UK." Review of Economics and Statistics 95 (4): 1278-1290.

Berry, J. W 1997. "Immigration, Acculturation and Adaptation." Applied Psychology 46 (1): 5-34.

Betts, J. R., and R. W. Fairlie. 2003. “Does Immigration Induce 'Native Flight' from Public Schools into Private Schools?” Journal of Public Economics 87 (5-6): 987-1012.

Binder, N., J. L. Polinard, and R. Wrinkle. 1997. "Mexican American and Anglo Attitudes toward Immigration Reform: A View from the Border." Social Science Quarterly 78 (2): 324-337.

Blinder, A. S 1973. "Wage Discrimination: Reduced Form and Structural Estimates." Journal of Human Resources 8: 436-455.

Borjas, C. J 1994. "The Economics of Immigration." Journal of Economic Literature 32 (4): 1667-1717.

Borjas, G. J 1999. “The Economic Analysis of Immigration." In Handbook of Labor Economics., edited by O. Ashenfelter, and D. Card, Vol. 3, 1st ed. 1697-1760. Elsevier.

Borjas, G. ] 2003. “The Labor Demand Curve Is Downward Sloping: Re-Examining the Impact of Immigration on the Labor Market." Quarterly Journal of Economics 118 (4): 1335-1374.

Borjas, G. J., J. Grogger, and G. H. Hanson. 2012. “Comment: On Estimating Elasticities of Substitution.” Journal of the European Economic Association 10 (1): 198-223.

Bridges, S., and S. Mateut. 2014. "Should they Stay or Should they Go? Attitudes Towards Immigration in Europe." Scottish Journal of Political Economy 61 (4): 397-429.

Card, D 1990. “The Impact of the Mariel Boatlift on the Miami Labor Market." Industrial and Labor Relations Review 43 (2): 245-257.

Card, D 2001. "Immigrant Inflows, Native Outflows, and the Local Labor Market Impacts of Higher Immigration." Journal of Labor Economics 19 (1): 22-63.

Card, D 2012. "Comment: The Elusive Search for Negative Wage Impacts of Immigration." Journal of the European Economic Association 10 (1): 211-215.

Card, D., C. Dustmann, and I. Preston. Understanding Attitudes to Immigration: The Migration and Minority Module of the First European Social Survey. CReAM UCL, DP no. 03/05 2005.

Card, D., C. Dustmann, and I. Preston. 2012. "Immigration, Wages, and Compositional Amenties." Journal of the European Economic Association $10(1): 78-119$.

Carrington, W. J., and P. D. Lima. 1996. "The Impact of 1970s Repatriates from Africa on the Portuguese Labor Market." Industrial and Labor Relations Review 49 (2): 330-347.

Ceobanu, A. M., and X. Escandell. 2010. “Comparative Analysis of Public Attitudes toward Immigrants and Immigration Using Multinational Survey Data: A Review of Theories and Research." Annual Review of Sociology 36: 309-328.

Citrin, J., D. P. Green, C. Muste, and C. Wong. 1997. "Public Opinion toward Immigration Reform: The Role of Economic Motivations." The Journal of Politics 59 (3): 858-881.

Constant, A. F., and K. F. Zimmermann. 2013. "Migration, Ethnicity and Economic Integration." In International Handbook on the Economics of Migration., edited by M. N. Jovanovic, 13-36. Cheltenham, UK, and Northampton, USA: Edward Elgar Publishing.

Department for Communities and Local Covernment and Ipsos MORI. 2007-2010. Citizenship Survey, 2007-2010 Colchester, Essex: UK Data Archive.

(Department for Communities and Local Covernment and Ipsos MORI) (2009-2010a).Citizenship Survey 2007-08: Technical Report. October13 2014. http://webarchive.nationalarchives.gov.uk/20120919132719/http://www.communities.gov.uk/documents/statistics/pdf/1395313.pdf.

Department for Communities and Local Covernment and Ipsos MORI. 2009-2010b. Citizenship Survey, 2009-2010 Colchester, Essex: UK Data ArchiveOctober13 2014. http://dx.doi.org/10.5255/UKDA-SN-6733-1.

Dustmann, C., F. Fabbri, and I. Preston. The Local Labour Market Effects of Immigration in the UK. 2003; Royal Economic Society Annual Conference 2003, 70. Royal Economic Society Junehttp://ideas.repec.org/p/ecj/ac2003/70.html.

Dustmann, C., F. Fabbri, and I. Preston. 2005. “The Impact of Immigration on the British Labour Market.” The Economic Journal 115 (507):. F324-F341. 
Dustmann, C., T. Frattini, and I. Preston. 2013. “The Effect of Immigration along the Distribution of Wages." The Review of Economic Studies 80 (1): $145-173$.

Dustmann, C., and I. Preston. 2001. “Attitudes to Ethnic Minorities, Ethnic Context and Location Decisions.” The Economic Journal 111 (470): 353-373.

Dustmann, C., and I. Preston. 2004. "Is Immigration Cood or Bad for the Economy? Analysis of Attitudinal Responses." Research in Labor Economics 24: 3-34.

Dustmann, C., and I. Preston. 2007. "Racial and Economics Factors in Attitudes to Immigration." The B.E. Journal of Economics Analysis \& Policy 7 (1 (Advances)):. article no. 62.

Dustmann, C., and I. Preston. 2012. “Comment: Estimating the Effect of Immigration on Wages.” Journal of the European Economic Association 10 (1): $216-223$.

Espenshade, T. J., and K. Hempstead. 1996. "Contemporary American Attitudes toward U.S. Immigration." International Migration Review 30 (2): 535-570.

Facchini, G., A. M. Mayda, and M. Mendola. 2013. “What Drives Individual Attitudes Towards Immigration in South Africa?” Review of International Economics 21 (2): 326-341.

Fetzer, ]. S. The evolution of public attitudes toward immigration in Europe and the United States, 2000-2010 2011; San Domenico di Fiesole (FI): European University Institute: Robert Schuman Centre for Advanced Studies, EU-US Immigration Systems No. 2011/10.

Friedberg, R. M., and ]. Hunt. 1995. "The Impact of Immigrants on Host Country Wages, Employment and Growth." The Journal of Economic Perspectives 9 (2): 23-44.

Gang, I. N., F. L. Rivera-Batiz, and M. Yun. 2013. “Economic Strain, Education and Attitudes Towards Foreigners in the European Union.” Review of International Economics 21 (2): 177-190.

Ceay, C., S. McNally, and S. Telhaj. 2013. “Non-Native Speakers of English in the Classroom: What are the Effects on Pupil Performance?” The Economic Journal 123 (570):. F281-F307.

Cordon, M 1964. Assimilation in American Life: The Role of Race, Religion and National Origin. New York: Oxford University Press.

Hainmueller, J., and M. J. Hiscox. 2007. "Educated Preferences: Explaining Attitudes toward Immigration in Europe." International Organization 61 (2): 399-442.

Hainmueller, J., and D. J. Hopkins. 2014a. "Public Attitudes toward Immigration." Annual Review of Political Science 17: $225-249$.

Hainmueller, J., and D. J. Hopkins. 2014b (October) 15. "The Hidden American Immigration Consensus: A Conjoint Analysis of Attitudes toward Immigrants." American Journal of Political Science 1-20. October152015.. Advance online publicationhttp://web.stanford.edu/jhain/Paper/comparative.pdf. DOI:10.1111/ajps.12138.

Haisken-DeNew, J. P., and K. F. Zimmermann. 1994. “Native Wage Impacts of Foreign Labor: A Random Effects Panel Analysis." Journal of Population Economics 7 (2): 177-192.

Haisken-DeNew, J. P., and K. F. Zimmermann. 1999. "Wage and Mobility Effects of Trade and Migration." In International Trade and Employment: The European Experience., edited by M. Dewatripont, and A. Sapir, 139-160. Oxford University Press.

Heath, A. F., S. D. Fischer, G. Rosenblatt, D. Sanders, and M. Sobolewska. 2013. The Political Integration of Ethnic Minorities in Britain. Oxford: Oxford University Press.

Hickman, M., H. Crowley, and N. Mai. 2008. Immigration and Social Cohesion in the UK: The Rhythms and Realities of Everyday Life. The Homestead, York: Joseph Rowntree Foundation.

Hood, M. V., I. Morris, and K. Shirkey. 1997. “Quedate O Vente!: Uncovering the Determinants of Hispanic Public Opinion toward Immigration." Political Research Quarterly 50 (3): 627-647.

Hunt, ] 1992. "The Impact of the 1962 Repatriates from Algeria on the French Labor Market." Industrial and Labor Relations Review 45 (3): 556-572.

Just, A., and C. J. Anderson. 2015. “Dual Allegiances? Immigrants' Attitudes toward Immigration.” The Journal of Politics 77 (1): $188-201$.

Kuhn, P., and I. Wooton. 1991. "Immigration, International Trade and the Wages of Native Workers." In Immigration, Trade and Labor., edited by J. M. Abowd, and R. B. Freeman. Chicago: University of Chicago Press.

LaLonde, R. J., and R.H. Topel. 1991. “Labor Market Adjustments to Increased Immigration.” In Immigration, Trade and Labor., edited by J. M. Abowd, and R. B. Freeman. Chicago: University of Chicago Press.

LaLonde, Robert, J., and R. H. Topel. 1996. "Economic Impact of International Migration and the Economic Performance of Immigrants." In Handbook of Population and Family Economics., edited by M. R. Rosenzweig, and O. Stark. North Holland, Amsterdam: Elsevier Science B.V.

Malchow-Moller, N., J. R. Munch, S. Schroll, and J.R. Skaksen. 2008. “Attitudes Towards Immigration - Perceived Consequences and Economic Self-Interest." Economics Letters 100: 254-257.

Malchow-Moller, N., J. R. Munch, S. Schroll, and J. R. Skaksen. 2009. ““'Explaining Cross-Country Differences in Attitudes Towards Immigration in the EU-15"." Social Indicators Research 91: 371-390.

Manacorda, M., A. Manning, and J. Wadsworth. 2012. "The Impact of Immigration on the Structure of Wages: Theory and Evidence from Britain." Journal of the European Economic Association 10 (1): 120-151.

Manning, A., and S. Roy. 2010. “Culture Clash or Culture Club? National Identity in Britain.” The Economic Journal 120 (542):. F72-F100.

Markaki, Y., and S. Longhi. 2013. "What Determines Attitudes to Immigration in European Countries? An Analysis at the Regional Level." Migration Studies 1 (3): 311-337.

Mayda, A. M 2006. "Who Is against Immigration? A Cross-Country Investigation of Individual Attitudes toward Immigrants." Review of Economics and Statistics 88 (3): 510-530.

Nielsen, I., O. Paritski, and R. Smyth. 2012. “A Minority-Status Perspective on Intergroup Relations: A Study of an Ethnic Chinese Population in A Small Italian Town." Urban Studies 49 (2): 307-318.

O'Connell, M 2011. "How Do High-Skilled Natives View High-Skilled Immigrants? A Test of Trade Theory Predictions." European Journal of Political Economy 27: 230-240.

Oaxaca, R 1973. “Male-Female Wage Differentials in Urban Labor Markets." International Economic Review 14: 693-709. 
Ohinata, A., and J. V. van Ours. 2013. "How Immigrant Children Affect the Academic Achievement of Native Dutch Children." The Economic Journal 123 (570):. F308-F331.

ONS. Migration Statistics Quarterly 2012.

ONS. 2014. October132014. http://www.ons.gov.uk/ons/about-ons/index.html.

Ortega, F., and J. G. Polavieja. 2012. “Labor-Market Exposure as a Determinant of Attitudes toward Immigration.” Labour Economics 19: 298-311.

Ottaviano, G. I. P., and G. Peri. 2012. “Rethinking the Effect of Immigration on Wages." Journal of the European Economic Association 10 (1): 152-197.

Pischke, J., and J. Velling. 1997. “Employment Effects of Immigration to Cermany: An Analysis Based on Local Labor Markets." The Review of Economics and Statistics 79 (4): 594-604. MIT Press.

Polinard, J., R. Wrinkle, and R. de la Garza. 1984. "Attitudes of Mexican Americans toward Irregular Mexican Immigrants." International Migration Review 18 (3): 782-899.

Rustenbach, E 2010. “Sources of Negative Attitudes toward Immigrants in Europe: A Multi-Level Analysis." International Migration Review 44 (1): 53-77.

Saggar, S., W. Somerville, R. Ford, and M. Sobolewska. (2012).The impacts of migration on social cohesion and integration London: Home Office. May 02 2016. https://www.gov.uk/government/uploads/system/uploads/attachment_data/file/258355/social-cohesionintegration.pdf.

Sanchez, G. R., and N. Masouka. 2010. "Brown-Utility Heuristic? The Presence and Contributing Factors of Latino Linked Fate." Hispanic Journal of Behavioural Sciences 32 (4): 519-531.

Scheve, K. F., and M. J. Slaughter. 2001. "Labor Market Competition and Individual Preferences over Immigration Policy." The Review of Economic and Statistics 83 (1): 133-145.

Schneeweis, N. Immigrant concentration in schools: Consequences for native and migrant students 2013; The Austrian Center for Labor Economics and the Analysis of the Welfare State, Johannes Kepler University Linz, Austria, Institute for the Study of Labor, IZA DP No. 7230.

Stanley, J., J. Stanley, and D. Hensher. 2012. “Mobility, Social Capital and Sense of Community: What Value?" Urban Studies 49 (16): 3595-3609.

Vervoort, M 2012. "'Ethnic Concentration in the Neighbourhood and Ethnic Minorities' Social Integration: Weak and Strong Social Ties Examined." Urban Studies 49 (4): 897-915.

Winter-Ebmer, R., and J. Zweimuller. 1996. "Immigration and the Earnings of Young Native Workers." Oxford Economics Papers 48 (3): $473-491$.

Winter-Ebmer, R., and ]. Zweimuller. 1999. “Do Immigrants Displace Young Native Workers: The Austrian Experience." Journal of Population Economics 12 (2): 327-340. 